\title{
FREEZABILITY, DNA INTEGRITY AND FERTILIZING CAPACITY OF SPERMATOZOA OF FRIESIAN BULLS TREATED WITH ANTI - HELMINTHIC DRUGS
}

Tag El-Dein, M. A.*; A. E. B. Zeidan*; Nabila I. El-Desouki**; Ghada A. Tabl ${ }^{\star *}$ and Rabab A. Kamel ${ }^{* *}$

* Animal Production Research Institute, Dokki, Giza, Egypt.

** Department of Zoology, Faculty of Science, Tanta University, Egypt.

\begin{abstract}
Effect of three different anti-helminthic drugs (ivermectin, levamisole and albendazole) on quality and fertility of spermatozoa of frozen-thawed semen of Frisian bulls .Animals were divided into four groups, control untreated group, and bulls treated with $200 \mu \mathrm{g} / \mathrm{kg}$ of ivermectin (IVM), $7.5 \mathrm{mg} / \mathrm{kg}$ of levamisole (LEV), and $10 \mathrm{mg} / \mathrm{kg}$ of albendazole (ABZ), respectively. The drugs used at two doses with 8-week interval between first and second dose. Semen was collected for $8^{\text {th }}$ weeks after each dose, extended, and frozen for two months, then post-thawing motility, freezability, intact acrosome and DNA integrity were determined. After the second dose, bulls treated with IVM and LEV significantly $(P<0.05)$ increased post-thawing motility, freezability and intact acrosome. Bulls treated with IVM did not negatively influenced DNA integrity, while LEV treatment affected negatively on DNA integrity by increasing tail moment percentage. Either first or second doses of $A B Z$ did not negatively affect post-thawing motility, freezability, intact acrosome and DNA integrity. Fertility rates of the cows artificially inseminated with the frozen-thawed semen were significantly $(P<0.05)$ higher when they were inseminated with semen of bulls treated with IVM or LEV and untreated bulls (control) than those treated with ABZ. In conclusion, treatment of Friesian bulls with Ivermectin as anti-helminthic drug at a level of 200 $\mu \mathrm{g} / \mathrm{kg}$ live body weight improved post-thawing motility and freezability of spermatozoa, percentage of spermatozoa with intact acrosome, and maintained DNA integrity and subsequent fertilizing efficiency of bull spermatozoa as compared to control bulls or bulls treated with Levamisole $(7.5 \mathrm{mg} / \mathrm{kg})$ or Albendazole $(10 \mathrm{mg} / \mathrm{kg})$ either after the first or second dose.

keywords: Friesian bulls, frozen semen, anti-helminthic, motility, DNA integrity, fertility.
\end{abstract}

\section{INTRODUCTION}

The male sexual functions are very sensitive to pharmacological agents and many chemicals and physical agents generated by industrial or agricultural activities (Spira and Multigner, 1998 and Favareto et al., 2011). Different chemical classes of Pesticides and solvents have been demonstrated to be male reproductive toxicants in animal models (Sundaram and Witorsch, 1995).

Research findings have shown that drugs, both synthetic and natural products, have considerable effects on the male reproductive system, especially the spermatozoa of domestic animals and men (Etta et al., 2009). Also, agricultural chemicals were found to reduce semen quality in fertile men (Swan et al., 2003). Studies focused on the effects of anti-parasitic drugs that 
Tag El-Dein, M. A. et al.

cause a transitory depression of fertility (Kayum et al., 1992; Kumar et al., 1992 and Raisinghani, 1992).

Ivermectin, albendazole, and levamisole are the most used antiparasitic drugs in sheep, goats, cattle, horses and pigs and was recommended against a variety of nematodes as well as trematodes (Cordero del Campillo, 1999).

On the other hand, improper diluents and preservatives may cause various physical changes like breaking of tail, cell surface destruction, loss of motility and loss of DNA integrity. Sperm DNA integrity is an important criterion for the success of natural or assisted fertilization including normal development of the embryo, fetus or offspring, transmission of genetic information and therefore, the maintenance of good health in future generations (add REF).

Lack of studies on the effects of anti-helminthic on frozen semen quality and DNA integrity under farm conditions has a drawback to clearly monitor the productivity of such animals. For this reason, the purpose of this study is to shed some light on the direct effect, and to evaluate possible male reproductive health-related problems associated with the use of antihelminthic drugs. Fertility rate and DNA integrity of the frozen-thawed bull spermatozoa treated with different anti-helminthic drugs were also assessed.

\section{MATERIALS AND METHODS}

The present work was carried out at El-Karada Animal Production Research Station, El-Karada Village, Kafrelsheikh Governorate, located in the North Eastern part of the Nile Delata $\left(31^{\circ} \mathrm{N}\right)$, belonging to Animal Production Research Institute, Agricultural Research Center, Egypt, during the period from May, 2009 to April, 2010.

Animals:

Sixteen Friesian bulls with an initial live body weight of $380 \pm 10.2 \mathrm{~kg}$ and aged 20 months were used in the present study. They were randomly divided into four groups (4 in each). All bulls were healthy and clinically free of external and internal parasites. Bulls in group 1 were untreated acting as control group, while those in groups 2, 3 and 4 were treated with ivermectin (200 $\mathrm{\mu g} / \mathrm{kg}$, subcutaneously), levamisole $\mathrm{HCl}(7.5 \mathrm{mg} / \mathrm{kg}$, subcutaneously) and albendazole (10 mg/kg, orally), respectively, as a first dose. The second dose repetition was administered after 8 weeks from the first dose. Ivermectin (Paramectin) and levamisole $\mathrm{HCl}$ (Levapan 10\%) were supplied by Pharma Swede, Egypt. Albendazole (Delta zole 10\%) was supplied by Delta Pharma, Egypt.

Semen was collected from all groups biweekly by means of an artificial vagina between 08.00 and 09.00 a.m. Two successive ejaculates were obtained from each bull at each day of collection (Collection period of 8 weeks). 


\section{Freezing semen procedures: \\ Semen extension:}

Semen was evaluated immediately after collection, then extended with Tris-yolk fructose (TYF) extender containing $3.028 \mathrm{~g}$ tris aminomethane, $1.675 \mathrm{~g}$ citric acid anhydrous, $1.25 \mathrm{~g}$ fructose, $7 \%$ glycerol, $20 \mathrm{ml}$ egg yolk, $500 \mathrm{IU}$ penicillin and $500 \mu \mathrm{g}$ streptomycin added to $100 \mathrm{ml}$ distilled water (Salisbury et al., 1978). The final extension rate pre-freezing was 1 semen: 20 extender (Salisbury et al., 1978).

\section{Equilibration period:}

Extended semen was kept at $5{ }^{\circ} \mathrm{C}$ for $4 \mathrm{~h}$ as an equilibration period. Then, the cooled semen was packaged in straws and frozen in liquid nitrogen $\left(-196^{\circ} \mathrm{C}\right)$ as the method described by Salisbury et al. (1978).

\section{Evaluation of frozen-thawed semen:}

Frozen semen in straws was thawed by holding the straws at the closed end (not plugged end) and was dipped in water bath at $37^{\circ} \mathrm{C}$ for 30 seconds. The percentages of post-thawing motility, acrosomal damage and freezability (recovery rate) of spermatozoa were recorded.

Freezability of the individual samples was examined as a percentage of spermatozoa recovered after freezing and thawing according to Patt and Nath (1969) using the following formula:

\section{motility (\%)\} X 100 .}

Freezability (recovery rate \%) $=\{$ Post-thawing motility (\%)/Initial

\section{Acrosomal damage (\%):}

A drop of the extended semen was smeared on a pre-warmed slide and dried in a current of warm air. The smears were fixed by immersion in dried formal saline (Campbell et al., 1956) in water bath at $37^{\circ} \mathrm{C}$ for 15 minutes. The slides were washed in the buffered Giemsa stain for 90 minutes after which it was rained briefly in distilled water and dried. Percentage of spermatozoa with damaged acrosome was determined by using Giemsa stain procedure as the method described by Watson (1975) using phase contrast microscope.

\section{Determination of DNA integrity:}

It was determined using a modified alkaline single cell gel electrophoresis (Comet) assay (Boe Hansem et al., 2005) to measure sperm DNA damage degree (Rojas et al., 1999).

\section{Fertility rate:}

Eighty normally cyclic Friesian cows (in heat) were artificially inseminated with the frozen/thawed bull semen. Cows were divided into four groups. The cows in the all groups were artificially inseminated with the frozen-thawed semen of untreated (control) bulls, and treated ones with ivermectin $(200 \mu \mathrm{g} / \mathrm{kg} / \mathrm{b} . \mathrm{w})$, levamisole $(7.5 \mathrm{mg} / \mathrm{kg} / \mathrm{b} . \mathrm{w})$ and albendazole (10 $\mathrm{mg} / \mathrm{kg} / \mathrm{b} . \mathrm{w}$ ) after the first and second doses, respectively. For each cow, two inseminations were carried out, one in the morning and another in the evening. Inseminations were usually carried out on the same day if cows were notified to be heat before 10.0 hrs requests received by the center after this time were locked to be inseminated on the following day. The straws were dipped immediately into thermos at $35^{\circ} \mathrm{C}$ for 30 seconds. The number of motile spermatozoa per insemination was nearly about $20 \times 10^{6}$ for each straw 
Tag El-Dein, M. A. et al.

$(0.25 \mathrm{ml})$. Semen was deposited into the uterus by using recto-vaginal insemination technique (Salisbury et al., 1978).

Conception rate was estimated on the basis of pregnancy diagnosis by the rectal palpation after 60 days from the date of insemination.

\section{Statistical analysis:}

Data were presented as the mean $\pm S E$ and statistically analyzed using SPSS statistical analysis software. The significant group differences were determined by Duncan's multiple range tests (Duncan, 1955). P values less than 0.05 were considered significant. The fertility rate results were analyzed using Chi-square test.

\section{RESULTS}

\section{Evaluation of frozen-thawed semen:}

\section{Post-thawing motility and freezability rate:}

Data presented in Table (1) show that after the first dose, significant $(P<0.05)$ decrease of the percentage of post-thawing motility and freezability of spermatozoa of bulls treated with LEV and ABZ as compared to that produced by untreated bulls and bulls treated with IVM. After the second dose, the percentages of post-thawing motility and freezability of spermatozoa of bulls treated with $A B Z$ significantly $(P<0.05)$ decreased as compared to IVM, LEV and untreated bulls. Generally, the highest $(P<0.05)$ value of post-thawing motility and freezability of spermatozoa was recorded for bulls treated with IVM, while the lowest $(P<0.05)$ value was observed for bulls treated with $A B Z$ after the first or second dose.

Table (1): Effect of anti-helminthic treatment (ivermectin, levamisole and albendazole) after the first and second dose on average postthawing motility, freezability and acrosome status of Friesian bull spermatozoa .

\begin{tabular}{|c|c|c|c|c|c|}
\hline \multirow{2}{*}{ Item } & \multirow{2}{*}{ Dose } & \multirow{2}{*}{$\begin{array}{l}\text { Control } \\
\text { group }\end{array}$} & \multicolumn{3}{|c|}{ Treatment group } \\
\hline & & & IVM & LEV & ABZ \\
\hline \multirow{2}{*}{ Post-thawing motility (\%) } & $1^{\mathrm{st}}$ & $50.88 \pm 2.16^{\mathrm{a}}$ & $50.00 \pm 2.49^{a}$ & $41.78 \pm 2.18^{b}$ & $41.11 \pm 2.19^{b}$ \\
\hline & & $45.23 \pm 1.49^{b}$ & $56.30 \pm 2.50^{\mathrm{a}}$ & $55.40 \pm 1.66^{a}$ & $30.50 \pm 1.82^{c}$ \\
\hline \multicolumn{2}{|c|}{ Mean (post-two doses) } & $48.06 \pm 3.12^{b}$ & $53.15 \pm 3.16^{b}$ & $48.59 \pm 2.16^{\mathrm{a}}$ & $35.81 \pm 1.92^{c}$ \\
\hline \multirow{2}{*}{ Freezability (\%) } & $1^{\text {st }}$ & $67.84 \pm 1.92^{a}$ & $66.66 \pm 2.33^{a}$ & $55.71 \pm 2.97^{b}$ & $54.81 \pm 2.36^{b}$ \\
\hline & $2^{\text {nd }}$ & $60.31 \pm 1.20^{b}$ & $75.07 \pm 3.18^{a}$ & $73.86 \pm 2.39^{a}$ & $40.66 \pm 0.53^{c}$ \\
\hline \multicolumn{2}{|c|}{ Mean (post-two doses) } & $64.07 \pm 3.61^{b}$ & $70.86 \pm 2.11^{b}$ & $64.48 \pm 1.87^{\mathrm{a}}$ & $47.67 \pm 1.74^{c}$ \\
\hline \multirow{2}{*}{$\begin{array}{c}\text { Spermatozoa with Intact } \\
\text { acrosome (\%) }\end{array}$} & $1^{\mathrm{st}}$ & $83.47 \pm 2.93^{a}$ & $71.55 \pm 3.93^{b}$ & $85.89 \pm 1.67^{a}$ & $69.62 \pm 1.55^{b}$ \\
\hline & $2^{\text {nd }}$ & $81.43 \pm 1.35^{b}$ & $82.72 \pm 1.36^{a}$ & $78.10 \pm 2.81^{\mathrm{b}}$ & $56.53 \pm 1.79^{c}$ \\
\hline \multicolumn{2}{|l|}{ Mean (post-two doses) } & $82.45 \pm 6.82^{c}$ & $77.13 \pm 2.20^{b}$ & $82.00 \pm 1.97^{a}$ & $63.08 \pm 2.02^{b}$ \\
\hline
\end{tabular}

a, b and c: Means denoted within the same row with different superscripts are significantly different $(P<0.05)$.

Data were represented as mean $\pm S E$.

Control: untreated bulls, IVM: Ivermectin, LEV: Levamisole and ABZ: Albendazole.

\section{Spermatozoa with intact acrosome:}

After the first dose, the percentage of spermatozoa with intact acrosome (Plate 1) in semen of untreated bulls and those treated with LEV 
was significantly $(P<0.05)$ higher than that of bulls treated with IVM or $A B Z$. The highest $(P<0.05)$ and lowest $(P<0.05)$ values of the percentage of intact acrosome were recorded for bulls treated with LEV and ABZ, respectively. After the second dose, bulls treated with IVM showed significantly $(P<0.05)$ higher percentage of spermatozoa with intact acrosome $(82.72 \pm 1.36)$ than that of untreated or bulls treated with LEV or ABZ. Generally, the highest $(P<0.05)$ and lowest $(P<0.05)$ values of spermatozoa with intact acrosome were observed for bulls treated with IVM and ABZ, respectively (Table 1).

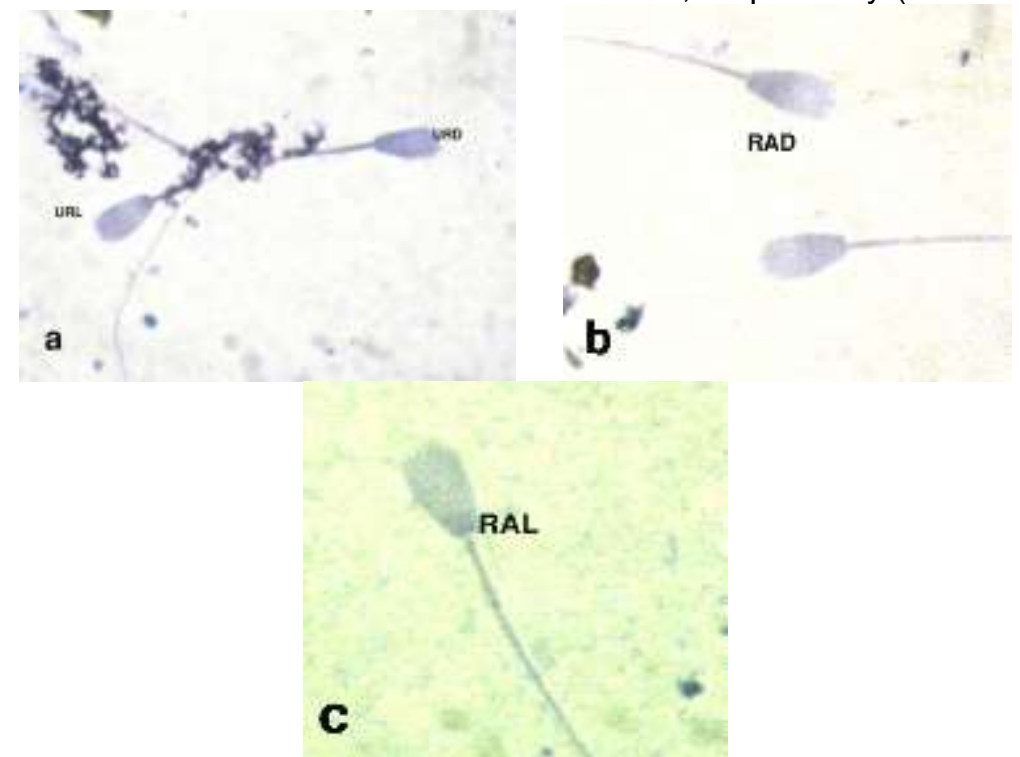

Plate (1): Photomicrograph of living and dead spermatozoa stained with trypan blue \& Giemsa stain showing (a) living spermatozoa with unreacted "intact" acrosome (URL) and dead spermatozoa with unreacted acrosome (URD), (b) dead spermatozoa with reacted acrosomes (RAD), and (c) living spermatozoa with reacted acrosome (RAL). (Trypan blue \& Giemsa stain, $\mathbf{x 1 0 0 0 )}$

\section{DNA integrity:}

The images of DNA integrity (Comet assay) with fluorescent microscope as affected by different anti-helminthic drugs (IVM, LEV and ABZ) are shown in Plate (2).

It is possible to compute DNA damage from Comet visually according to Comet appearance. The obtained results revealed 5 classes, from 0 (no tail) to 4 (almost all DNA in the tail). By using software, the most commonly used parameters are tail length (TL), relative fluorescence intensity of tail (TI) and head $(\mathrm{HI})$,and tail moment (TM) as the distance between centers of mass $\mathrm{X} \%$ tail DNA.

Tail length:

After the first dose, the present results (Table 2) show that sperm tail length of spermatozoa of bulls treated with IVM, LEV or ABZ significantly 
Tag El-Dein, M. A. et al.

$(P<0.05)$ increased as compared to that of untreated bulls. While, sperm tail length of spermatozoa of bulls treated with LEV and ABZ significantly $(P<0.05)$ increased as compared to that of bulls treated with IVM. Generally, the highest $(P<0.05)$ and lowest $(P<0.05)$ sperm tail length values were recorded for $A B Z$ and untreated bulls, respectively. After the second dose, bulls treated with LEV or ABZ significantly $(P<0.05)$ increased sperm tail length as compared to control, and bulls treated with IVM. The highest $(P<0.05)$ and lowest $(P<0.05)$ tail length were recorded for $A B Z$ and untreated bulls, respectively. The mean of two doses showed significant $(P<0.05)$ increase in sperm tail length for bulls treated with $A B Z$, LEV and IVM as compared to untreated bulls.

Tail and head intensity (\%):

After the first dose, bulls treated with $A B Z$ showed significantly $(P<0.05)$ higher tail intensity, and significantly $(P<0.05)$ lower head intensity than untreated bulls (control). The highest $(P<0.05)$ values of tail intensity and head intensity were recorded for bulls treated with ABZ and IVM, respectively. While, the lowest $(P<0.05)$ values of tail intensity and head intensity were recorded with bulls treated with IVM and ABZ, respectively (Table 2).

After the second dose, bulls treated with $A B Z$ showed significantly $(P<0.05)$ higher tail intensity, and significantly $(P<0.05)$ lower head intensity than untreated bulls or bulls treated with IVM and LEV. However, there was significant $(P<0.05)$ decrease of tail intensity of spermatozoa of bulls treated with IVM and LEV as compared to untreated bulls. The highest $(P<0.05)$ value of tail intensity and head intensity were recorded for bulls treated with $\mathrm{ABZ}$ and IVM, respectively (Table 2 ).

Table (2): Effect of anti-helminthic treatment (ivermectin, levamisole and albendazole) after the first and second dose on DNA integrity of frozen-thawed bull semen.

\begin{tabular}{|c|c|c|c|c|c|}
\hline \multirow{2}{*}{ Item } & \multirow{2}{*}{ Dose } & \multirow{2}{*}{ Control group } & \multicolumn{3}{|c|}{ Treatment group } \\
\hline & & & IVM & LEV & ABZ \\
\hline Tail length & $\begin{array}{l}1^{\text {st }} \\
2^{\text {nd }}\end{array}$ & $\begin{array}{c}67.23 \pm 5.83^{\mathrm{c}} \\
140.47 \pm 5.17^{\mathrm{c}}\end{array}$ & $\begin{array}{c}103.02 \pm 6.69^{\mathrm{b}} \\
164.76 \pm 7.59 \mathrm{~A}^{\mathrm{bc}}\end{array}$ & $\begin{array}{r}130.80 \pm 6.65^{\mathrm{a}} \\
185.46 \pm 7.31^{\mathrm{ab}}\end{array}$ & $\begin{array}{c}148.22 \pm 6.52^{\mathrm{a}} \\
203.81 \pm 13.68^{\mathrm{a}}\end{array}$ \\
\hline \multicolumn{2}{|c|}{ Mean (post-two doses) } & $103.85 \pm 4.77^{d}$ & $133.89 \pm 5.35^{\mathrm{c}}$ & $158.13 \pm 5.18^{b}$ & $176.01 \pm 7.73^{a}$ \\
\hline Tail intensity (\%) & $\begin{array}{l}1^{\text {st }} \\
2^{\text {nd }}\end{array}$ & $\begin{array}{c}9.28 \pm 0.76^{b} \\
11.74 \pm 0.44^{b}\end{array}$ & $\begin{array}{l}9.18 \pm 0.48^{b} \\
9.31 \pm 0.52^{c}\end{array}$ & $\begin{array}{l}9.43 \pm 0.58^{b} \\
9.38 \pm 0.54^{c}\end{array}$ & $\begin{array}{l}16.14 \pm 0.81^{\mathrm{a}} \\
14.10 \pm 0.85^{\mathrm{a}}\end{array}$ \\
\hline \multicolumn{2}{|c|}{ Mean (post-two doses) } & $10.51 \pm 0.44^{b}$ & $9.24 \pm 0.35^{b}$ & $9.41 \pm 0.40^{b}$ & $15.12 \pm 0.59^{\mathrm{a}}$ \\
\hline Head intensity (\%) & $\begin{array}{l}1^{\text {st }} \\
2^{\text {nd }}\end{array}$ & $\begin{array}{l}90.72 \pm 0.76^{\mathrm{a}} \\
88.26 \pm 0.44^{\mathrm{b}}\end{array}$ & $\begin{array}{l}90.82 \pm 0.48^{\mathrm{a}} \\
90.69 \pm 0.52^{\mathrm{a}}\end{array}$ & $\begin{array}{l}90.57 \pm 0.58^{\mathrm{a}} \\
90.62 \pm 0.54^{\mathrm{a}}\end{array}$ & $\begin{array}{l}83.86 \pm 0.81^{b} \\
85.90 \pm 0.85^{c}\end{array}$ \\
\hline \multicolumn{2}{|c|}{ Mean (post-two doses) } & $89.49 \pm 0.44^{a}$ & $90.76 \pm 0.35^{a}$ & $90.59 \pm 0.40^{a}$ & $84.88 \pm 0.59^{b}$ \\
\hline \multirow[t]{2}{*}{\begin{tabular}{|l|l} 
Tail moment & \\
\end{tabular}} & $\begin{array}{l}1^{\text {st }} \\
2^{\text {nd }}\end{array}$ & $\begin{array}{c}5.74 \pm 0.45^{\mathrm{c}} \\
10.80 \pm 0.00^{\mathrm{b}}\end{array}$ & $\begin{array}{l}6.75 \pm 0.18^{b c} \\
11.40 \pm 0.19^{b}\end{array}$ & $\begin{array}{c}9.51 \pm 0.06^{b} \\
12.48 \pm 1.26^{b}\end{array}$ & $\begin{array}{l}18.24 \pm 1.40^{\mathrm{a}} \\
26.61 \pm 1.58^{\mathrm{a}}\end{array}$ \\
\hline & Mean (post-two doses) & $8.27 \pm 0.80^{b}$ & $9.07 \pm 0.70^{b}$ & $11.00 \pm 0.60^{b}$ & $22.43 \pm 2.40^{a}$ \\
\hline
\end{tabular}

a, b and c: Means denoted within the same row with different superscripts are significantly different $(\mathrm{P}<0.05)$.

Data were represented as means \pm SE.

Control: untreated bulls, IVM: Ivermectin, LEV: Levamisole and ABZ: Albendazole. 

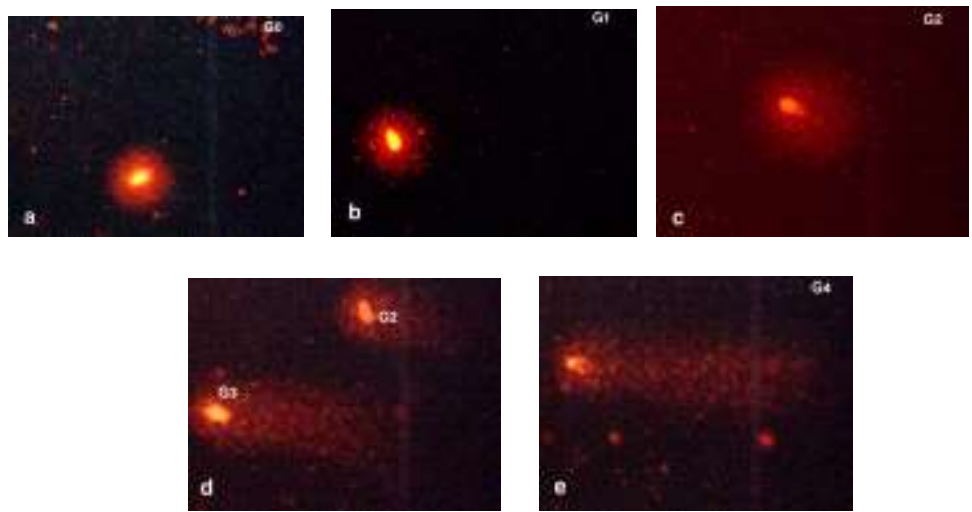

Plate (2): Image of DNA integrity with fluorescent microscope (Comet assay) under the influence of different anti-helminthic drugs (IVM, LEV or ABZ) showing: (a) intact and undamaged DNA, Grade 0, (b) slight damage of DNA, Grade 1, (c). moderate damage of DNA, Grade 2, (d) high degree of DNA damage, Grade 3, and (e) destructive degree of DNA damage, Grade 4.

\section{Tail moment:}

After the administration of the bulls with $A B Z$ as first dose, tail moment showed significant $(P<0.05)$ increase as compared to control or bulls treated with IVM and LEV. Also, tail moment in the bulls treated with LEV significantly $(P<0.05)$ increased as compared to untreated bulls (Table 2$)$.

After the second dose, tail moment showed significant $(P<0.05)$ increase for bulls treated with $A B Z$ as compared to control, or those treated with IVM and LEV. Similarly, the mean of two doses in bulls treated with ABZ recorded significant $(P<0.05)$ increase in tail moment as compared to control or bulls treated with IVM and LEV. The highest $(P<0.05)$ value of tail moment was recorded for bulls treated with $A B Z$, while the lowest $(P<0.05)$ value was observed in the untreated bulls after the first and second dose. Bulls treated with IVM or LEV recorded moderate comet tail moment (Table 2).

\section{Fertility rate:}

Data in Table (3) show that conception rates (CR) of the cows artificially inseminated with frozen-thawed semen of bull treated with IVM, LEV and ABZ and untreated control bulls were 63..64, 62.50, 58.33 and $66.67 \%$ after the first dose, and $54.54,70.00,55.55$ and $50.00 \%$ after the second one, respectively. These results revealed that frozen-thawed semen of bull treated with IVM significantly $(P<0.05)$ improved fertility rate of inseminated cows as compared to those inseminated with semen of bulls treated with $A B Z$, and insignificantly improved $C R$ of cows inseminated with semen of bulls treated with other drugs or untreated bulls (control) after the first dose. However, after the second dose, semen of bulls treated with IVM or LEV significantly $(\mathrm{P}<0.05)$ improved fertility rate as compared to those treated with $A B Z$ or controls (Control). 
Tag El-Dein, M. A. et al.

Table (3): Conception rates of Friesian cows artificially inseminated with the frozen-thawed semen after the first and second dose of bulls treated with different anti-helminthic drugs.

\begin{tabular}{|c|c|c|c|c|}
\hline \multirow{2}{*}{ Item } & \multirow{2}{*}{$\begin{array}{l}\text { Control } \\
\text { group }\end{array}$} & \multicolumn{3}{|c|}{ Treatment group } \\
\hline & & IVM & LEV & ABZ \\
\hline \multicolumn{5}{|c|}{ Number of inseminated cows: } \\
\hline Post- $1^{\text {st }}$ dose & 11 & 8 & 12 & 9 \\
\hline Post $-2^{\text {nd }}$ dose & 11 & 10 & 9 & 10 \\
\hline \multicolumn{5}{|c|}{ Number of conceived cows: } \\
\hline Post- $1^{\text {st }}$ dose & 7 & 5 & 7 & 5 \\
\hline Post $-2^{\text {nd }}$ dose & 6 & 7 & 6 & 5 \\
\hline \multicolumn{5}{|c|}{ Conception rate (\%): } \\
\hline Post- $1^{\text {st }}$ dose & 63.64 & 62.50 & 58.33 & 66.67 \\
\hline Post- $2^{\text {nd }}$ dose & $54.54^{b}$ & $70.00^{\mathrm{a}}$ & $55.55^{b}$ & $50.00^{b}$ \\
\hline
\end{tabular}

a, b and c: Means denoted within the same row with different superscripts are significantly different $(P<0.05)$.

Data were represented as mean \pm SE.

Control: untreated bulls, IVM: Ivermectin, LEV: Levamisole and ABZ: Albendazole.

\section{DISCUSSION}

The present results demonstrated that bulls treated with ivermectin or levamisole didn't negatively influence on quality and freezability of bull spermatozoa, although ivermectin treatment had a favorable effect on fertility as most sperm parameters examined significantly improved as compared to the untreated bulls. In contrary, bulls treated with albendazole either after the first or second dose decreased physical semen characteristics as well as quality and freezability of bull spermatozoa.

Based on our findings, the negative effect of albendazole treatment is in agreement with of the results of Bakst et al. (2006), who showed that albendazole treatment deleteriously affected sperm motility. Albendazole may be genotoxic to human lymphocytes in vivo (Ozats et al., 2007). Also, the reported results on rats showed that high dose of albendazole oxide was embryotoxic and lower dose $(7 \mathrm{mg} / \mathrm{kg} / \mathrm{day})$ caused impairment of foetal development (EMEA, 1999). Reproductive effects of albendazole $(5.8 \mathrm{mg} / \mathrm{kg}$ LBW/day) were investigated on multi-generation orally dosing rats; it caused reduced survival and growth of pups during the post-natal lactation period (EMEA, 2004).

Although the sperm motility is important for semen quality, bull sperm motility alone does not secure fertilizing capacity. Spermatozoa with intact acrosome are needed to penetrate the barriers around the ovum. The acrosome is more susceptible to damage during storage than the organelles, being the structural basis of motility. This presumption is in accordance with experiments performed by Buhr (1990), who stated that the decrease of membrane fluidity during storage is greater for head plasma membranes than for sperm body membranes. The present results revealed that bulls treated with IVM and LEV produced semen containing spermatozoa characterized by significantly $(P<0.05)$ higher post-thawing motility, freezability and intact acrosome. In contrary, bulls treated with $A B Z$ showed spermatozoa having significantly $(\mathrm{P}<0.05)$ lower post-thawing motility, freezability and intact 
acrosome. This decrease in acrosomal integrity might be due to membrane damage, which is in accordance with the results of Holt and North (1994), who reported that virtually $100 \%$ of spermatozoa subjected to freezing exhibited plasma membrane loss or damage of the head region. In addition, acrosomes were partially disrupted by freezing and thawing; many acrosomes became swollen, between 50 and $85 \%$ of spermatozoa maintained outer acrosomal membrane integrity after freezing to $-10^{\circ} \mathrm{C}$ or -30 ${ }^{\circ} \mathrm{C}$. Also, Zeidan et al. (2004) reported that the increase of hyaluronidase enzyme released into the seminal plasma with the advancement of storage or incubation times may be attributed to the increase of acrosomal damage. Moreover, Lenz et al. (1977) and Jones and Stewart (1979) indicated that extension and cooling of bull semen to $5^{\circ} \mathrm{C}$ caused acrosomal swelling in about $50 \%$ of spermatozoa. Subsequent freezing and thawing caused considerable ultra-structural changes to the acrosomes (disruption of the plasma and outer acrosomal membranes and disruption of the acrosomal contents) and middle pieces (breakage of plasma membrane and a reduction in the electron density of the mitochondrial matrix) of a high proportion of spermatozoa.

In addition, normal structure of sperm chromatin is essential for the fertilizing ability of spermatozoa in vivo (Erenpreiss et al., 2006). Sperm chromatin structural integrity of several animal species and a man has been extensively studied and has been shown to be correlated with fertility (Evenson et al., 2000 and Evenson and Jost, 2000). In contrary, Salsabili et al. (2006) showed that there was no correlation between sperm nuclear chromatin condensation and semen parameters. Assessing sperm morphology, motility, and concentration is the best way to investigate male fertility. These are the 3 most important factors in male reproduction potential (Liu et al., 1988 and Ombelet et al., 1997). However, these parameters have not been proven useful in predicting the results of assisted reproductive technology (Sakkas et al., 1996). Therefore, more sensitive diagnostic techniques to identify sub-fertility enable to the therapeutic options must be developed (Aitken, 1990).

Sperm chromatin structure assay is considered highly stable and robust, having the least inter-assay variation compared with other methods for measuring DNA integrity (Evenson et al., 2002 and Perreault et al., 2003). Although the evaluation of semen quality may provide some indication of the function of the testis and sperm, it does not provide information on the condition of the male genome contained in sperm heads (Morris, 2002). The integrity of sperm DNA is centre to the transmission of genetic information during reproduction and chromatin abnormalities or DNA damage can a result in paternal fertility problems (Evenson et al., 2002 and Agarwal and Said, 2003). In this respect, Mckelveymartin et al. (1997) mentioned that fertile spermatozoa are more resistant to damage by agents that induce DNA breakdown than infertile samples. Rahmy (1998) added that DNA depletion due to Echis carinatus envenomation included most spermatogenic cells but not luminal spermatozoa. Possible reproductive toxicants such as pesticides may affect the normal disjunction of chromosomes during meiosis, therefore altering the number of chromosomes in sperm nuclei. 
Tag El-Dein, M. A. et al.

In this study, albendazole treatment (both first and second dose) resulted in the highest DNA damage in term of significantly increase of tail length, tail intensity (the percentage of DNA in comet tail) and tail moment as compared to untreated and other treated bulls. Levamisole treatment also caused DNA damage where it significantly increased tail length and tail moment. Bull treated with Ivermectin showed the least DNA damage among anti-helminthic groups by increasing tail length and decreasing tail intensity as compared to the control group. So, it can be concluded that ivermectin may be haven't harmful effect on DNA integrity in Friesian bull semen. These results are in accordance with findings of Sanchez-Pena et al. (2004) and Rubes et al. (2005), who showed that exposure to pesticides (organophosphates) and air pollution has also been associated with increased levels of sperm DNA damage. Additionally, of two studies using the Comet assay to measure percent Comet tail DNA, one study found an association with the pyrethroid fenvalerate (Bian et al., 2004), while in the $2^{\text {nd }}$ study they found associations with the carbamate carbaryl and the organophosphate chlorpyrifos (Meeker et al., 2004). Pyrethroids are known to disrupt mammalian and amphibian germ cell formation, whereas the testicular toxicity of carbaryl has been demonstrated in rats (Pant et al., 1996). Sanchez-Pena et al. (2004) found associations between the organophosphate (OP) metabolite diethlythiophosphate and DNA fragmentation index. OPs are considered potent alkylating agents and alkylating agents are potentially genotoxic to animal sperm by altering chromatin structure via binding to protamines and DNA, causing DNA to become more susceptible to induce denaturation in situ (Evenson et al., 1985). Moreover, Benzimidazole carbarnate compounds cause premature sloughing of germ cells along with cleaved processes of Sertoli cell cytoplasm (Hess et al., 1991 and Nakai and Hess, 1997), necrosis of mitotic spermatogonia and meiotic spermatocytes (Nakai and Hess, 1997) and seminiferous tubular atrophy (Carter et al., 1987; Hess et al., 1991 and Nakai et al., 1997). The proposed mechanism contributing to sloughing is deformation of Sertoli cell cytoplasm due to the disruption of microtubules (Nakai et al., 1997).

In contrary, cytogenetic study revealed partial effect of ivermectin on meiosis through reducing number of spermatocytes at metaphase II (M-II). Meanwhile, the combined treatment of ivermectin plus verapamil induced stronger effect on germ cells, as they reduce number of spermatocytes at $\mathrm{M}$ II. Increased number of the structural chromosomal aberrations at spermatogonial metaphase and $M-I I$ and increased frequency of $X-Y$ chromosome dissociation at metaphase I $(\mathrm{M}-\mathrm{I})$, raise the attention to the genetic quality of mature sperm which need further investigation (El-Nahas and El-Ashmawy, 2008).

Abnormal sperm chromatin/DNA structure is thought to arise from four potential sources: 1) deficiencies in recombination during spermatogenesis, which usually lead to cell abortion; 2) abnormal spermatid maturation (protamination disturbances); 3) abortive apoptosis; and 4) oxidative stress (Sakkas et al., 1999 and Agarwal and Said, 2003). A significant association between male sub-fertility, imperfect spermiation and 
abnormal nuclear condensation has been suggested. The DNA content of spermatozoa might be responsible for inducing alterations in sperm morphology. The final nuclear shape, which is species-specific, depends on chromatin condensation during spermatogenesis as well as a precise organization of DNA within the nucleus. Many reports have described the association between disturbances in sperm chromatin condensation, morphology and male infertility (Bach et al., 1990 and Foresta et al., 1992).

Spermatogenesis is characterised by two distinct stages, spermatocytogenesis and spermiogenesis. Spermatocytogenesis consists of the mitotic divisions involving proliferation and maintenance of spermatogonia (Senger, 1999). Spermatogonia then undergo meiosis to form primary spermatocytes and then secondary spermatocytes, which differentiate into spermatids. Spermatids can be divided into three categories: early spermatids with round nuclei, intermediate spermatids with elongating nuclei, and mature spermatids with condensed nuclei (Dadoune, 2003). DNA damage due to apoptosis has been found to occur in the testis during spermatogenesis, predominately at the spermatogonia and dividing cells level (Sakkas, et al., 1999 and Print and Loveland, 2000). The increased sensitivity to DNA damage in abnormal spermatozoa is probably due to failed chromatin condensation, which makes the DNA more accessible to damage (Sakkas et al., 1999).

Infertile men as compared with fertile controls, have an increased sperm histone: protamine ratio (Oliva, 2006). An excess of nuclear histones $(>15 \%)$ results in poorer chromatin compaction and a subsequent increased susceptibility to external stresses (e.g., oxidation or temperature elevation in the female reproductive tract) (Kosower et al., 1992). It has been shown that the proposed antiparasitic mechanism of action for the artesmisinins is through generation of free radicals- reactive oxygen species (Robert et al., 2000), with resulting in vitro and in vivo mitochondrial injury (Aitken et al., 2003). Furthermore, oxidative stress causes injury to genomic integrity in male germinal cells, resulting in infertility (Sharma and Agarwal, 1996). Thus, oxidative stress induced by artesunate in seminal fluid, could directly or indirectly impair spermatogenesis and reproductive dysfunction (Obianime and Aprioku, 2009).

The present investigation showed that the bulls treated with ivermectin gave better fertility rate than the bulls treated with albendazole or control bulls. The highest fertility rate of frozen-thawed bull semen treated with ivermectin was mainly related to the best improvement of the postthawing sperm motility, freezability, as well as, the lowest of acrosomal damage of spermatozoa. In addition, such effects resulted in fewer changes in spermatozoal functions and resulted in DNA integrity in the frozen-bull spermatozoal subsequently better spermatozoa motility in the bulls administrated with ivermectin. These results are in agreement with those of Rickard et al. (1992), who showed that ivermectin administration increased conception rates. Moreover, Janett et al. (2001) ivermectin treatment had a favorable effect on stallion fertility. 


\section{CONCLUSION}

In conclusion, treatment of Friesian bulls with Ivermectin as antihelminthic drug at a level of $200 \mu \mathrm{g} / \mathrm{kg}$ live body weight improved postthawing motility and freezability of spermatozoa, percentage of spermatozoa with intact acrosome, and maintained DNA integrity and subsequent fertilizing efficiency of bull spermatozoa as compared to control bulls or bulls treated with Levamisole $(7.5 \mathrm{mg} / \mathrm{kg})$ or Albendazole $(10 \mathrm{mg} / \mathrm{kg})$ either after the first or second dose. Therefore, it can be recommended to treatment of bulls with ivermectin at level of $200 \mu \mathrm{g} / \mathrm{kg}$ live body weight for artificial insemination programmes to enhance fertility rate. Anti-helminthic as levamisole could be used carefully with bulls especially during breeding season. Albendazole treatment had harmful effects on semen quality, DNA integrity and subsequent post-thawing motility and freezability of spermatozoa and consequently fertility rate.

\section{REFERENCES}

Agarwal, A. and Said, T. M. (2003): Role of sperm chromatin abnormalities and DNA damage in male infertility. Hum. Reprod., 9:331-345.

Aitken, R. J. (1990): Evaluation of human sperm function. Br. Med. Bull., 46 : $654-74$

Aitken, R. J.; Baker, M. A. and Sawyer, D. (2003): Oxidative stress in the male germ line and its role in the aetiology of male infertility and genetic disease. Reprod. Biomed., 7:65-70.

Bach, O.; dander, H. J.; Scholz, G. and Schwarz, J. (1990): Electrophoretic patterns of spermatozoal nucleoprotems (NP) in fertile men and infertile patients and comparison with NP of somatic cells. Andrologia, 22: 217224.

Bakst, R.; Kramer, M. and Long, J. (2006): Effect of fenbendazole on turkey semen quality. J. Appl. Poult. Res., 15:307-311.

Bian, Q.; Xu, L. C.; Wang, S. L.; Xia, Y.K.; Tan, L. F.; Chen, J.F.; Song, L.; Chang, H.C. and Wang, X. R. (2004): Study on the relation between occupational fenvalerate exposure and spermatozoa DNA damage of pesticide factory workers. Occup. Environ. Med., 61: 999-1005.

Boe-Hansen, B.; Morris, D. and Ersboll, K. (2005): DNA integrity in sexed bull sperm assessed by neutral Comet assay and sperm chromatin structure assay. Theriogenology, 63: 1789-1802.

Buhr, M. M. (1990): Preservation of boar sperm alters membrane molecular dynamics. Proc. 2nd Int. Conf. Boar Semen Preserv. Beltsville, 81-93.

Campbell, R. C.; Dott, H. M. and Glover, T. D. (1956): Nigrosin eosin as stain for differentiating live and dead spermatozoa. J. Agric. Sci., 48, 1-8.

Carter, S. D.; Hess, R. A and Laskey, J. W. (1987): The fungicide methyl 2 benzimidazole carbarnate causes infertility in male Sprague-Dawley rats Biology of Reprod., 37: 709-717.

Cordero del Campillo, M. (1999): Parasitologia Veterinaria. McGraw-HillInteramericana de España, S.A.U.; Madrid. 
Dadoune, J. P. (2003): Expression of mammalian spermatozoal nucleoproteins. Micros. Res. Tech., 61: 56-75.

El-Nahas, A. F. and El-Ashmawy, I. M. (2008): Effect of ivermectin on male fertility and its interaction with P-glycoprotein inhibitor (verapamil) in rats. Environmental Toxicology and Pharmacology, 26: 206-211.

EMEA. (1999): Committee for veterinary medicinal products, albendazole oxide. Summary report (2). EMEA/MRL/555/99-Final.

EMEA. (2004): Committee for medicinal products for veterinary use, albendazole, summary report (3). EMEA/865/03-Final.

Erenpreiss, J.; Spano, M.; Erenpreisa, J.; Bungum, M. and Giwercman, A. (2006): Sperm chromatin structure and male fertility: biological and clinical aspects. Asian J. Androl., 8:11-29.

Etta, H. E.; Bassey, U. P.; Eneobong, E. E. and Okon, O.B. (2009): Antispermatogenic effects of ethanol extract of Mucuna urens. J. Reprod. Contraception, 20: 161-168.

Evenson, D. P.; Higgins, P. H.; Grueneberg, D. and Ballachey, B. (1985): Flow cytometric analysis of mouse spermatogenic function following exposure to ethylnitrosourea. Cytometry, 6: 238-253.

Evenson, D. and Jost, L. (2000): Sperm chromatin structure assay is useful for fertility assessment. Methods in Cell Science, 22:169-189.

Evenson, D. P.; Larson, K. L. and Jost, L.K. (2002): Sperm chromatin structure assay: its clinical use for detecting sperm DNA fragmentation in male infertility and comparisons with other techniques. J. Androl., 23: 25-43.

Favareto, A. P. A.; Fernandez, C. D. B.; da Silva, D. A. F.; Anselmo-Franci, J. A. and Kempinas, W. D. G. (2011): Persistent Impairment of Testicular Histology and Sperm Motility in Adult Rats Treated with Cisplatin at Peri-Puberty. Basic \& Clinical Pharmacology \& Toxicology, 109: no. doi: $10.1111 / j .1742-7843.2011 .00688 . x$

Foresta, C.; Zorzi, M.; Rossoto, M. and Varotto, A. (1992): Sperm nuclear instability and staining with aniline blue abnormal persistence of histones in spermatozoa in infertile men. Int. J. Androl., 15: 330-337.

Hess, R. A.; Moore, B. J.; Forrer, L.; Linder, R. E. and Abuel-Atta, A. A. (1991): The fungicide benomyl (methyl 1-(butylcarbamoyl)- 2benzinddazolecarbamate) causes testicular dysfunction by inducing the sloughing of germ cells and occlusion of efferent ductules Fundamental and Applied. Toxicology, 17: 733-745.

Holt, W. V. and North, R. D. (1994): Effects of temperature and restoration of osmotic equilibrium during thawing on the induction of plasma membrane damage in cryopreserved ram spermatozoa. Biol. Reprod., 51: 414.

Janett, F.; Thun, R.; Ryhiner, A.; Burger, D.; Hassig, M. and Hertzberg, H. (2001): Influence of Eqvalan (ivermectin) on quality and freezability of stallion semen. Theriogenology, 55: 785

Jones, R. C. and Stewart, D. L. (1979): The effects of cooling to $5^{\circ} \mathrm{C}$ and freezing and thawing on the ultrastructure of bull spermatozoa. J. Reprod. Ferti., 56: 233-238 
Kayum, A.; Afzal, M. and Salman, R. (1992): Gastrointestinal parasites in racing camels: prevalence and evaluation of different methods of fecal examinations. In: Proceedings of the $1^{\text {st }}$. International Camel Conference, United Arab Emirates, pp85-87.

Konca, K.; Lankoff, A. and Banasik, A. (2003): A cross-platform public domain PC image -analysis program for the Comet assay. Mutat. Res., 534:15-20.

Kosower, N. S.; Katayose, H. and Yanagimachi, R. (1992): Thiol-disulfide status and acridine orange fluorescence of mammalian sperm nuclei. $J$. Androl., 13: 342-8.

Kumar, D.; Raisinghani, P. M. and Manohar, G. S. (1992): Sarcoptic mange in camels: a review. In: Proceedings of the Ist. International Camel Conference, United Arab Emirates, PP79-82.

Lenz, R. W.; Graves, C. N. and Lodge, J. R. (1977): Influence of incubation in seminal plasma on subsequent metabolic and morphological characteristics of bovine spermatozoa. Theriogenology, 7: 265-275

Liu, D. Y.; Du Plessis, Y. P.; Nayudu, P. L.; Johnston, W. I. and Baker, H. W. (1988): The use of in vitro fertilization to evaluate putative tests of human sperm function. Fertil. Steril., 49: 272-7.

Mckelveymartin, V. J.; Melia, N.; Walsh, I. K.; Johnston, S. R.; Hughes, CM.; Lewis, S. M. and Thompson, W. (1997): Potential clinical-applications of the alkaline single-cell gel-electrophoresis assay. Human bladder washings and transitional-cell carcinoma of the bladder. Human sperm and male-infertility. Mutat. Res. Fundam. Mol. Mech. Mutagen., 375: 93-104.

Meeker, J. D.; Singh, N. P.; Ryan, L.; Duty, S.M.; Barr, D. B.; Herrick, R. F.; Bennett, D. H. and Hauser, R. (2004): Urinary levels of insecticide metabolites and DNA damage in human sperm. Hum Reprod., 19: 2573-2580.

Morris, I. D. (2002): Sperm DNA damage and cancer treatment. Int. J. Androl., 25: 255-61.

Nakai, M. and Hess, R. A. (1997): Effects of carbendazim (methyl 2benzindiazole carbarnate; MBC) on meiotic spermatocytes and subsequent spermiogenesis in the rat testis. Anatomical Record, 247:379-387

Obianime, A. W. and Aprioku, J. S. (2009): Comparative study of Artesunate, ACTs and their combinations on the spermatic parameters of the male guinea pig. Nigerian J. Physiological Sci., 24: 1 -6.

Oliva, R. (2006): Protamines and male infertility. Hum. Reprod. Update, 12: 417-35.

Ombelet, W.; Pollet, H.; Bosmans, E. and Vereecken, A. (1997): Results of a questionnaire on sperm morphology assessment. Hum. Reprod., 12: 1015-20.

Ozats, S.; Salman, A.; Tatar, A.; Yigiter, M.; Yazgi, H.; Ertek, M.; Yesilyur, A. and Kursad, H. (2007): Genotoxic effect of albendazole in pediatric patients with hepatic hydatid disease. Int. J. Infect. Dis., 11: 446-449.

Pant, N.; Shankar, R. and Srivastava, S. P. (1996): Spermatotoxic effects of carbaryl in rats. Hum. Exp. Toxicol ., 15: 736-738.

Patt, J. A. and Nath, J. (1969): Effect of diluents, equilibration time and freezing rates on storage of ram semen. Cryobiology, 5: 385-392. 
Perreault, S. D.; Aitken, R. J.; Baker, H. W.; Evenson, D. P. and Huszar, G.; Irvine, D. S. (2003): Integrating new tests of sperm genetic integrity into semen analysis: breakout group discussion. Adv. Exp. Med. Biol., 518: 253- 268.

Print, C. G. and Loveland, K. L. (2000): Germ cell suicide: new insights into apoptosis during spermatogenesis. Bio.assay, 22:423-30.

Rahmy, T. R. (1998): Histological, histochemical and morphometrical studies on the actions of Echis carinatus snake venom on the testicular tissues. J. Union. Arab. Biol., 9: 51-72.

Raisinghani, P. M. (1992): Helminthic diseases of the dromedary camels in India. In: Proceedings of the $1^{\text {st }}$ International Camel Conference, United Arab Emirates, PP105-106.

Rickard, L. G.; Zimmerman, G. L.; Hoberg, E. P.; Bishop, J. K. and Pettitt, R. J. (1992): Influence of ivermectin and clorsulon treatment on productivity of a cow-calf herd on the southern Oregon coast. Vet. Parasitol., 41: 45-55.

Robert, K. M.; Daryl, K. G.; Peter, A. M. and Victor, W. R. (2000): Harper's Biochemistry (25 ${ }^{\text {th }}$ ed.). Appleton: Lange. pp. 169- 170: 648-649.

Rojas, E.; Lopez, M. C. and Valverde, M. (1999): Single cell gel electrophoresis assay: methodology and applications. J. Chromatogr., 722:225-54.

Rubes, J.; Selevan, S. G. and Evenson, D. P (2005): Episodic air pollution is associated with increased DNA fragmentation in human sperm without other changes in semen quality. Hum. Reprod., 20: 2776-83.

Sakkas, D.; Urner, F. and Bianchi, P.G. (1996): Sperm chromatin anomalies can influence decondensation after intracytoplasmic sperm injection. Hum. Reprod., 11: 837-43.

Salisbury, G. W.; Van Denmark, N. L. and Lodge, J. R. (1978): Physiology of Reproduction and Artificial Insemination of Cattle. W. N. Freeman and Co. San Fransisco, USA.

Salsabili, N.; Mehrsai, A.; Jalalizadeh, B.; Pourmand, G. and Jalaie, S. (2006): Correlation of Sperm Nuclear Chromatin Condensation Staining Method with Semen Parameters and Sperm Functional Tests in Patients with Spinal Cord Injury, Varicocele, and Idiopathic Infertility. Urology Journal, 3: 32-37.

Sanchez-Pena, L. C.; Reyes, B. E.; Lopez-Carrillo, L.; Recio, R.; MoranMartinez, J. and Cebrian, M. E. (2004): Quintanilla-Vega B. Organophosphorous pesticide exposure alters sperm chromatin structure in Mexican agricultural workers. Toxicol. Appl. Pharmacol., 196:108-113.

Senger, P. L. (1999): Pathways to Pregnancy and Parturition, 1st ed. Current Conceptions Inc.; Washington.USA.

Sharma, R. K. and Agarwal, A. (1996): Role of reactive oxygen species in male infertily. Urol., 48: 835-850.

Spira, A. and Multigner, L. (1998): The effect of industrial and agricultural pollution on human spermatogenesis. Hum. Reprod., 13: 2041-2042

Sundaram, K. and Witorsch, R. (1995): Toxic Effects on The Testes. In Witorsch, R. (ed.), Reproductive Toxicology. Raven Press, New York, pp 99-122. 
Tag El-Dein, M. A. et al.

Swan, S. H.; Kruse, R. L. and Lin, F. (2003): Semen quality in relation to biomarkers of pesticide exposure. Environ. Health Perspect., 111:1478-84.

Watson, P. P. (1975): Use of Giemsa stain to detect changes in acrosome of frozen ram spermatozoa. J. Vet. Res., 97:112

Zeidan, A. E. B.; Mohamed, M. M. and Abdel-Kariem, M. A. (2004): Survival rate, acrosomal status and conception rate of the cooled bovine spermatozoa supplemented with melatonin. Egyptian Soc. Anim. Reprod. Fert. Sixteen Annual Congers, pp 185-199.

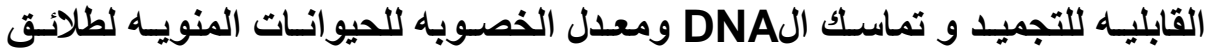

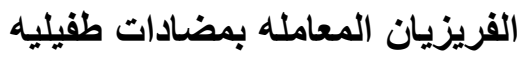

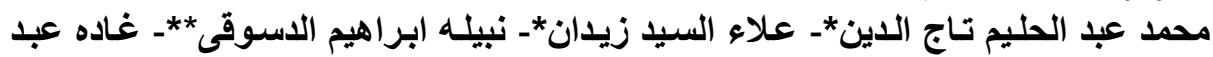

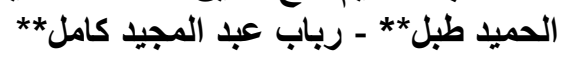

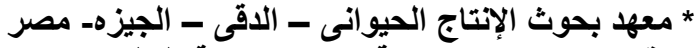

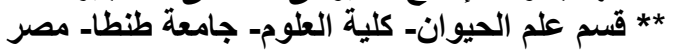

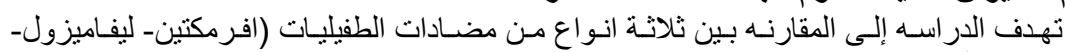

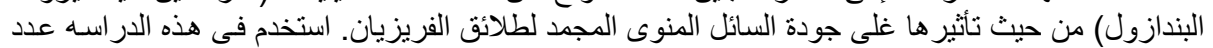

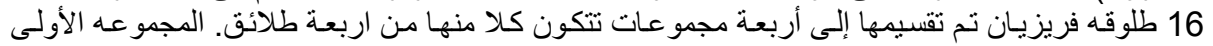

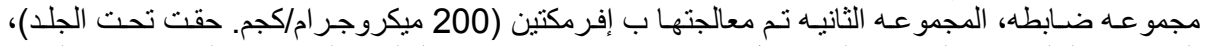

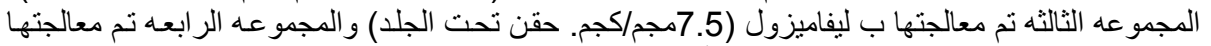

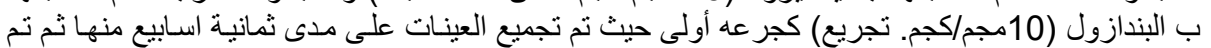

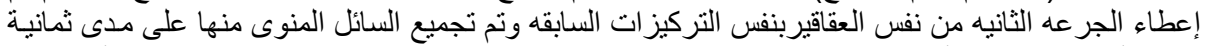

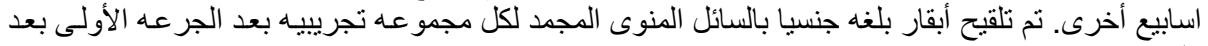

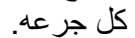

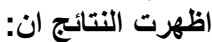

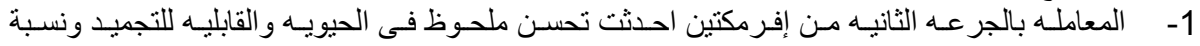

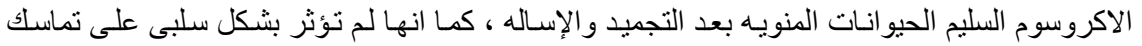

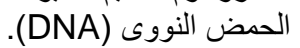

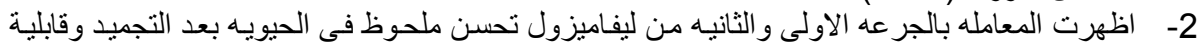

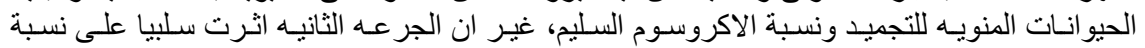

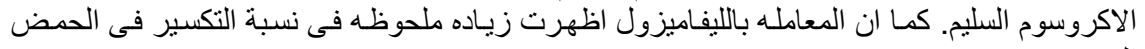

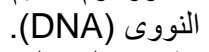

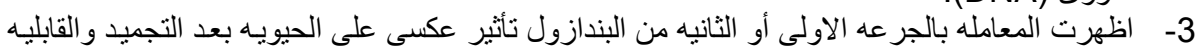

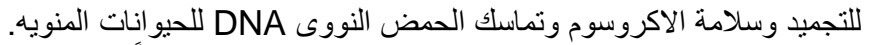

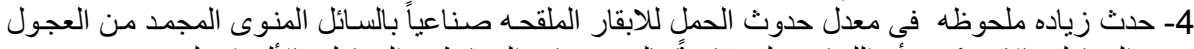

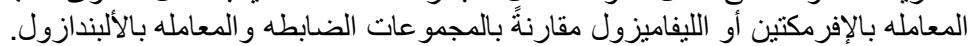

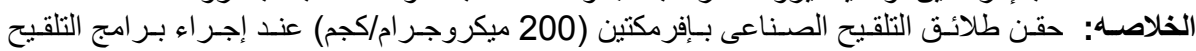

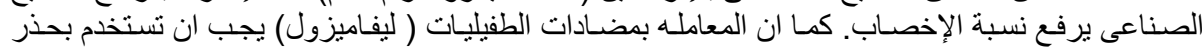

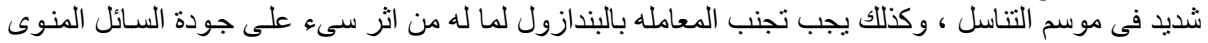

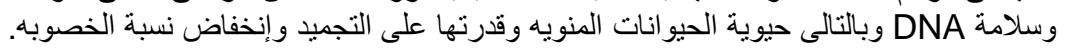

كلية الزراعة - جامعة المنصورة

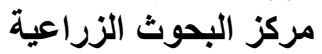

قام بتحكيم البحث إنداث

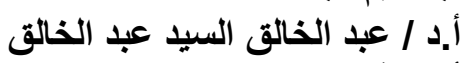

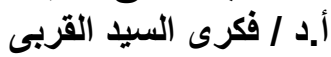


J. Animal and Poultry Prod., Mansoura Univ., Vol. 2 (8), August,2011

327 